\title{
A Survey on Renewable Energy Development in Malaysia: Current Status, Problems and Prospects
}

\author{
Syed Shah ALAM ${ }^{1 *}$, Nor Fariza Mohd NOR ${ }^{2}$, Maisarah AHMAD ${ }^{1}$, Nik Hazrul Nik HASHIM ${ }^{3}$ \\ ${ }^{I}$ Faculty of Economics and Management, Universiti Kebangsaan Malaysia, Pusat Teknologi Pintar \\ UKM-MTDC, 43600 Bangi, Selangor, Malaysia \\ ${ }^{2}$ Faculty of Social Sciences, Universiti Kebangsaan Malaysia, Pusat Teknologi Pintar \\ UKM-MTDC, 43600 Bangi, Selangor, Malaysia \\ ${ }^{3}$ Graduate School of Business, Universiti Kebangsaan Malaysia, Pusat Teknologi Pintar \\ UKM-MTDC, 43600 Bangi, Selangor, Malaysia
}

\begin{abstract}
Energy demand in Malaysia is increasing over seven per cent a year, while forty per cent of the energy is supplied from conventional fossil fuel. However, a number of social barriers have mired the social acceptance of renewable energy among the users. This study investigates the current status of renewable energy, problems and future outlook of renewable energy in Malaysia. A total of 200 respondents were surveyed from Klang Valley in Malaysia. Majority of the respondents use energy to generate electricity. Although some respondents reported using solar energy, there is lack of retail availability for solar energy. The findings show that limited information on renewable energy technologies, lack of awareness, and limited private sector engagement emerged as major barriers to sustainable renewable energy development. In addition, the respondents suggest for increasing policy support from the government to make information more accessible to mass users, provide economic incentives to investors and users, and promote small-community based renewable energy projects. The study suggests that the government begin small scale projects to build awareness on renewable energy, while academically, higher learning institutions include renewable energy syllabus in their academic curriculum. The study concluded that to have sustainable renewable energy development, government's initiative, private sector engagement and users awareness must be given priority.
\end{abstract}

Keywords - Renewable energy; Alternative energy; Malaysia; Attitude; Theory of planned behaviour

\section{INTRODUCTION}

Green and alternative energy technologies are utilitarian concepts that have emerged from the growing need of energy. To preserve the ecological balance of this planet, a major invention has been to motivate the users towards renewable energy technologies. Social, regulatory and technical know-how are the three major problems hindering the process of conversion to alternative energy [1]. Studies on alternative energy in developed country examine users' attitude towards renewable energy in order to understand the barriers embedded in the socialisation of renewable energy [2]-[6]. As an emerging economic power, Malaysia has been investing a large amount in energy safety. During 1990-2007, energy supply has grown, on the average, at $7 \%$ every year, of which, $40 \%$ has been collected from fossil fuel. However, the contribution of renewable energy has been negligible [7]. About $36 \%$ of energy comes from gas, $17 \%$ energy sources from coal and biomass. Waste make up another $4 \%$ energy and hydropower contributes to $3 \%$ of the total energy consumption in Malaysia. More importantly, the website of the

\footnotetext{
* Corresponding author.

E-mail address: shahalam@ukm.edu.my

(C)2016 Syed Shah Alam, Nor Fariza Mohd Nor, Maisarah Ahmad, Nik Hazrul Nik Hashim. This is an open access article licensed under the

Creative Commons Attribution License (http://creativecommons.org/licenses/by/4.0), in the manner agreed with De Gruyter Open.
} 
Department of Statistics' shows that Malaysia's export of conventional energy is around $30 \%$ of their gross domestic product during 2007-2009, which is against the environmental safety principle of the country.

Social acceptance of renewable energy has been challenging for many users due to availability of less expensive energy alternatives. Apart from purely social fortune, households tendency towards new technology adoption is highly process oriented and a long-term dispute [8]-[10] because investment in renewable energy is expensive. New users only like to increase their energy budget not more than $5 \%$ in many developed countries [6], [11]. It is still at the primary stage to comment on the success of the retail channels to make renewable energy available to mass users. Moreover, users lifestyle, level of awareness and ease of technology use are factors which influence rapid acceptance of renewable energy [12]. Studies on renewable energy in Malaysia extensively cover the technical and regulatory advancements of new technology for mass use (Table 1). Studies on social barriers and users' attitude towards renewable energy are yet to emerge in public domain. Therefore, users' experience with and their attitude towards renewable energy is yet to be rightly explored.

\section{TABLE 1. A SUMMARY OF STUdies ON RENEWABLE ENERGy IN MALAYSiA}

\begin{tabular}{ll}
\hline Author(s) & Topic \\
\hline (Sovacool \& Bulan) [13] & Energy security and hydropower development in Sarawak, Malaysia. \\
(Ong, Mahlia \& Masjuki) [14] & Energy pattern and policy for transportation sector in Malaysia \\
(Mekhilef et al.) [15] & Current state and prospects of solar energy in Malaysia \\
(Chua \& Oh) [16] & Solar energy outlook in Malaysia \\
(Tye, Lee, Wan Abdullah \& Leh) [17] & Bioethanol as an energy source in Malaysia \\
(Sovacool \& Drupady) [18] & Small renewable energy power program in Malaysia \\
(Mohammed, Salmiaton, Wan Azlina, & Hydrogen rick gas from palm oil biomass as a potential renewable \\
Mohammad Amran, Fakhru'l-Razi \& & energy in Malaysia \\
Taufiq-Yap) [19] & \\
(Poh \& Kong) [20] & A policy analysis for renewable energy in Malaysia \\
(Hoi Why) [21] & Problems and prospects of biomass energy utilisation in Malaysia \\
(Mohd Noh) [22] & Renewable energy update in Malaysia \\
\hline
\end{tabular}

Malaysia's tropical-humid weather all year round makes it possible for Malaysia to explore solar energy opportunities [23]. Malaysian government has developed initiatives to encourage development of renewable energy, for instance, the government initiated Fit in Tariff (FiT) program to develop renewable energy use, which has taken place from year 2011 [24]. The Tenth Malaysia Plan (2011-2015) promotes the idea of energy efficiency in Malaysia and has put forward budgetary incentives for development of solar energy, palm-oil biomass and hydropower [23]. Chua and Oh [16] argue that such plans would help in developing alternative energy and assist in economic development in Malaysia.

However, studies summarised in Table 1 showed a sluggish progress from the eighth Malaysia plan (2001-2005) until the tenth Malaysia plan [25]. Sovacool and Drupady [18] explore a number of regulatory and social barriers with regard to the development on of small scale renewable energy in Malaysia. Among these barriers, community involvement, pricing versus tariff cost and lengthy approval process may involve created long-lasting dissatisfaction among the users' of renewable energy.

Renewable energy evolution is an outcome of the global awareness on green environmental. The first prudent attempt to restore greenness was to replace the use of plastic bags [26]. Gradually, biomass, waste management and community based small scale solar energy programs 
have shaped the renewable energy today [18]. Recent attempts to renewable energy development involve construction of large hydro-electric plants and windmill projects. It is evident that renewable energy development has shifted quickly from merely engaging mass users, towards institutional production and profit making. Stephenson and Loannou [5] found that the growth of renewable energy solutions in many countries has been very sluggish due to lack of understanding about the life standard of the users. To motivate the use of renewable energy, green technology policy and green building index have been introduced in 2009 [27], [28]. Findings from studies show that the idea of energy efficiency award system and investment tax incentive to promote use of renewable energy are growing [29]. Conversely, we know very little about how individuals' feel when they consider sustainable renewable energy solutions. It is therefore, of significant importance to examine users' interest in this renewable energy initiative, problems and solutions for renewable energy development in Malaysia.

Adequate and unstoppable energy supply is at the core of economic development. Renewable energy has been touted to help reduce the use of fossil fuel, restore the green environment and to reduce the future uncertainty of energy supply. However, Gan and Li's study [30] have shown otherwise. Their projections report that Malaysia's energy consumption and carbon emissions will be triple by 2030, and energy import dependency will rise. They concluded with the urge for prudent government's regulation on green technology and environmental safety. This study argues that alongside regulatory and technical developments, it is of utmost importance to understand the users' attitude and practice of renewable energy technology. To reiterate, the current study, therefore, attempts to explain and examine the current status of renewable energy and problems with it, in Malaysia. The study ends with suggestions for sustainable renewable energy development in Malaysia.

\section{EMPIRICAL DESIGN}

The study aims at understanding the current user profile and energy practice, challenges to renewable energy development, and future prospects and way out for sustainable renewable energy development in Malaysia. A total of 200 household from the Klang valley in Kuala Lumpur, Malaysia participated in the study. It was difficult to get users of renewable energy. Extensive brainstorming sessions with experts from marketing research and renewable energy suggested that the snow-ball sampling is the best method. With this sampling method, respondents are selected based on references given by existing respondents [31]. However, to have diversity into the sample, the current study used multiple starting points in different parts of the Klang Valley. Thus, instead of starting with one reference point, the data collection started with different reference points and data is collected until the data reaches saturation in the responses. Finally, a total of 200 completed responses were gathered for further analysis. Table 2 displays the respondents' profile. Gorsuch [32] and Kline [33] suggested sampling at least 100 subjects. A sample size of 200 persons is recommended to be sufficient for data analysis [34].

Data used in this study were categorised into three major groups. There were questions on current renewable energy practices, which were followed by questions on major barriers to renewable energy development, and opinion regarding future prospects and challenges of renewable energy development. The survey questions is the form of structured interview protocol, with close ended and a combination of dichotomous and multichotomous questions. Analyses of the questions were conducted in two stages. A number of descriptive statistics were done, followed by mean-difference tests using Analysis Of Variance (ANOVA). As argued in Faiers and Neame [12], this study hypothesises that ethnic difference (i.e. Malay vs. others), size of establishment (i.e. number of room in the house) and amount of electricity consumption (in kilowatts per month) 
posit differences in users current status of renewable energy use, problems with the energy use and solutions for renewable energy development.

\section{DisCuSSION OF FINDINGS}

\subsection{Level of Interest, Awareness, Current and Future Use of Renewable Energy}

Table 2 shows that over $70 \%$ of the respondents were from Malay ethnicity. $57 \%$ of the respondents had an establishment size of between 3-5 rooms in their houses. In total, around $90 \%$ of the respondents had five rooms or less in their residence. Almost two third of the respondents $(62 \%)$ own a house while the remaining were tenants. $33 \%$ of the respondents used below 500 kilowatts of electricity every month. However, nearly $87 \%$ of the respondents reported that they used a range of $0-3000$ Kilowatts of electricity. The profile elucidates that the respondents are mostly Malay households. Table 3 and 4 show the interests of the respondents' towards protecting the environment and their level of interest in renewable energy. On the average, $20 \%$ of the respondents do not want to be penalised for causing harm to the environment. Similary another $20 \%$ indicate that they have to think carefully before transforming themselves into supporters of renewable energy. Table 5 shows the reason behind this unfavourable acceptance.

Around $98 \%$ of the respondents use a combination of electricity and gas for heating water at home. Thus, the lack of interest in renewable energy is Malaysia is primarily contributed by the lack of available technology for mass use.

\section{TABLE 2. RESPONDENT PROFILE}

\begin{tabular}{lrrlrr}
\hline Ethnic Origin & & & Establishment size & & \\
& Freq. & $\%$ & & Freq. & $\%$ \\
\hline Malay & 146 & 73.0 & Below 3 Room & 63 & 31.5 \\
Chinese & 27 & 13.5 & 3-5 Rooms & 114 & 57.0 \\
Indian & 16 & 8.0 & 5-10 Rooms & 17 & 8.5 \\
Others & 11 & 5.5 & 10-20 Rooms & 1 & .5 \\
Total & $\mathbf{2 0 0}$ & $\mathbf{1 0 0 . 0}$ & More than 20 Rooms & 1 & .5 \\
& & & Total & $\mathbf{1 9 6}$ & $\mathbf{9 8 . 0}$ \\
& & & & & \\
\hline Average electricity use (kw/month) & & & Occupancy of the house & Freq. & $\%$ \\
\hline Below 500KWh & Freq. & $\%$ & & 124 & 62.0 \\
$500-1000 \mathrm{KWh}$ & 66 & 33.0 & Owned & 34.0 \\
1000-3000KWh & 63 & 31.5 & Rented & $\mathbf{1 9 2}$ & $\mathbf{9 6 . 0}$ \\
$3000-5000 \mathrm{KWh}$ & 45 & 22.5 & Total & & \\
$5000-10000 \mathrm{KWh}$ & 10 & 5.0 & & & \\
More than 10000 KWh & 8 & 4.0 & & & \\
Total & 4 & 2.0 & & &
\end{tabular}

Table 6 shows the level of awareness among respondents in Klang Valley. Around 20-25\% of the respondents are not alarmed by or aware of climactic and environmental changes which is taking place on the planet. Therefore, the lack of interest towards renewable energy is also contributed by lack of awareness in among nearly one third of the respondents. 
Table 7 shows the current state of renewable energy use. $31 \%$ of the respondents use solar nominal heating, $11 \%$ use solar for space heating, $6.6 \%$ use solar for pool heating and another $11 \%$ use photovoltaic energy conversion from solar to electricity. Additionally, $16.2 \%$ use thermal insulation for the house. It is evident from the data that respondents mostly use solar energy.

Table 8 shows that $54 \%$ of the respondents in future would like to rely on energy sources created out of renewable energy. Table 7 and 8 provide important information on users' lifestyle and priority regarding renewable energy in Malaysia. The data points to the fact that the government and private organisation should keep users' life standard in mind when designing renewable energy technology for mass use.

TABLE 3. WAYS TO PROTECT ENVIRONMENT (\% OF THE RESPONDENTS)

\begin{tabular}{lllll}
\hline Ways & Now & Later & Never & Total \\
\hline Use public transport than personal cars & 70.0 & 24.5 & 9.5 & 100.0 \\
Use environmentally friendly products & 56.0 & 39.0 & 5.0 & 100.0 \\
Practice recycling & 77.5 & 17.0 & 5.5 & 100.0 \\
Reducing wastage & 73.5 & 23.0 & 3.5 & 100.0 \\
Reduce the use of electricity & 75.5 & 21.5 & 3.0 & 100.0 \\
Pay higher taxes for environmental destruction & 38.0 & 40.0 & 22.0 & 100.0 \\
Participate in environmental safety & 73.0 & 22.0 & 5.0 & 100.0 \\
\hline
\end{tabular}

TABLE 4. LEVEL OF INTEREST IN RENEWABLE ENERGY

\begin{tabular}{lll}
\hline Level of Interest & Frequency & \% \\
\hline Very Little Interest & 42 & 21.0 \\
Average Interest & 73 & 36.5 \\
Very Much Interested & 85 & 42.5 \\
Total & 200 & 100.0 \\
\hline
\end{tabular}

TABLE 5. ENERGY USE FOR WATER HEATER

\begin{tabular}{lll}
\hline Methods & Frequency & \% \\
\hline Electricity & 115 & 57.5 \\
Gas & 23 & 11.5 \\
Electricity and Gas & 50 & 25.0 \\
Solar & 3 & 1.5 \\
Total & 191 & 95.5 \\
Missing & 9 & 4.5 \\
Total & 200 & 100.0 \\
\hline
\end{tabular}


Table 6. Are You Aware of Climactic and Environmental Changes (\% OF RESPONDENTS)?

\begin{tabular}{lllll}
\hline Alarmed by & Yes & No & Don't Know & Total \\
\hline Climate change & 78.5 & 9.5 & 12.0 & 100.0 \\
Animal extinctions & 76.5 & 13.5 & 10.0 & 100.0 \\
Pollution by human & 84.0 & 7.0 & 9.0 & 100.0 \\
Pollution by agriculture & 71.0 & 18.5 & 10.5 & 100.0 \\
Rapid Urbanisation & 79.0 & 11.0 & 10.0 & 100.0 \\
Increasing amount of waste & 76.0 & 12.5 & 11.5 & 100.0 \\
Obesity among people & 76.5 & 12.5 & 11.0 & 100.0 \\
Increase in transport flows & 76.0 & 13.5 & 10.5 & 100.0 \\
\hline
\end{tabular}

TABle 7. Current State of Renewable EnERgy Use

\begin{tabular}{lccc}
\hline \multirow{2}{*}{ Type of Renewable Energy } & \multicolumn{2}{c}{ Responses } & \multirow{2}{*}{ Percent of Cases } \\
\hline Thermal insulation of the house & N & \% & \\
Solar for heat & 44 & $16.2 \%$ & $24.6 \%$ \\
Solar space heating & 84 & $30.9 \%$ & $46.9 \%$ \\
Attached greenhouse & 30 & $11.0 \%$ & $16.8 \%$ \\
Solar pool heating & 51 & $18.8 \%$ & $28.5 \%$ \\
Photovoltaic electricity generation & 18 & $6.6 \%$ & $10.1 \%$ \\
Geothermal hot water/space heating & 31 & $11.4 \%$ & $17.3 \%$ \\
Use of solid fuel with biomass content & 4 & $1.5 \%$ & $2.2 \%$ \\
\hline & 10 & $3.7 \%$ & $5.6 \%$ \\
\hline No: $\%$. & 272 & $100.0 \%$ & $152.0 \%$ \\
\hline
\end{tabular}

Note: includes multiple responses

\subsection{Major Barriers to Renewable Energy Development}

Respondents identified their level of support for various renewable energy technology developments (Table 9) and commented on barriers they faced during the decision of renewable energy use (Table 10). On average, more than $5 \%$ of the respondents commented that they do not know about various energy technologies, which is why they are unable to support the use of renewable energy. The final column in Table 9 shows the total percentage of respondents' responses which are coded as strongly opposed, opposed and neutral. This column shows that another 30-40\% of the respondents either opposed or kept them aside from supporting. Lack of support from the respondents is perhaps contributed by the lack of awareness and access to information. Some of the factors which created barriers are presented in Table 10. Respondents selected lack of awareness and unfavourable cost as the two most important barriers (based on mean score). Limited private sector involvement, uneasy regulatory support from the government, limited social acceptance and unavailability of financial valuation information for user analysis were the other important factors.

One way ANOVA tests were conducted to examine whether the barriers were different among different categories of respondents. Null hypotheses means that each barrier is the same among the groups (such as among Malays, Chinese, Indians and others). Among the three categories, the 
size of establishments, ethnicity and electricity usage based on average per month, the study found two barriers. They are size of establishment and electricity usage based on average per month. The use of electricity is statistically significant (see Table 11). ANOVA tests on barriers signals two major problems. Firstly, limited access to renewable energy information among the minority groups (the Malay population is majority, Chinese and Indians are minority). Secondly, customers with one of the highest usage of electricity (500-1000 kW per month) in the retail sector could not find suitable renewable technology for their use. These two results, therefore, have implications on policymakers. The result indicates that information should be made available to all the potential users of renewable energy. In addition, companies that invest to produce renewable energy technology should work closely with the government to introduce renewable energy technologies that are suitable for the targeted users. As argued in Faiers and Neame [12] Stephenson and Loannou [5] and Rogers et al. [35], renewable energy initiatives will fail unless the regulators and investors pay attention to community interest and lifestyle of the users.

TABLE 8. FUtURE PRIORITY FOR RENEWABLE ENERGY USE

\begin{tabular}{lccc}
\hline \multicolumn{1}{c}{ Future use of Renewable Energy } & \multicolumn{2}{c}{ Responses } & \multirow{2}{*}{ Percent of Cases } \\
\hline Nuclear power plants & N & \% & \\
Power plants that rely on renewable energy & 46 & $18.4 \%$ & $24.2 \%$ \\
Natural gas power plants & 135 & $54.0 \%$ & $71.1 \%$ \\
Coal fired power plants & 57 & $22.8 \%$ & $30.0 \%$ \\
Others & 8 & $3.2 \%$ & $4.2 \%$ \\
\hline & 4 & $1.6 \%$ & $2.1 \%$ \\
\hline
\end{tabular}

Note: includes multiple responses

TABLE 9. LEVEL OF SUPPORT FOR RENEWABLE ENERGY

\begin{tabular}{lccccccc}
\hline Level of Support with & SO & $\mathbf{O}$ & $\mathbf{N}$ & $\mathbf{S}$ & SS & $\begin{array}{c}\text { Don't } \\
\text { Know }\end{array}$ & $\begin{array}{c}\text { SO+O } \\
+\mathbf{N}\end{array}$ \\
\hline Hydroelectric generation with a dam & 2.5 & 7.0 & 20.5 & 38.5 & 22.5 & 9.0 & 30.0 \\
Small hydroelectric on streams & 1.0 & 7.5 & 29.0 & 35.5 & 18.0 & 9.0 & 37.5 \\
Biomass/ Biodiesel & 2.0 & 6.0 & 21.0 & 40.0 & 26.0 & 5.0 & 29.0 \\
Wind energy & 1.5 & 6.0 & 22.0 & 33.5 & 29.5 & 7.5 & 29.5 \\
Solar thermal energy & 1.0 & 2.5 & 17.0 & 33.0 & 40.5 & 6.0 & 20.5 \\
Photovoltaic energy & 1.0 & 3.0 & 22.0 & 33.0 & 34.0 & 7.0 & 26.0 \\
Geothermal energy & 2.0 & 3.0 & 30.0 & 35.0 & 19.0 & 11.0 & 35.0 \\
Wood Energy & 4.5 & 12.0 & 32.0 & 28.5 & 15.0 & 8.0 & 48.5 \\
Oil Energy & 3.5 & 9.5 & 33.5 & 30.0 & 18.5 & 5.0 & 46.5 \\
Gas Energy & 4.0 & 8.5 & 32.0 & 29.0 & 22.0 & 4.5 & 44.5 \\
\hline No: & &
\end{tabular}

Note: rounded to $100 \%$; SO = Strongly Opposed, O = Opposed, N = Neutral, S = Supportive, SS = Strongly Supportive 
TABLE 10. MAJOR BARRIERS TO RENEWABLE ENERGY DEVELOPMENT (\% OF RESPONDENTS)

\begin{tabular}{lccccccc}
\hline Items & SD & D & MD & MA & A & SA & Mean \\
\hline Limited information on Renewable energy & 5.0 & 10.5 & 14.5 & 23.5 & 32.5 & 14.0 & 4.08 \\
Inadequate financing & 1.0 & 6.0 & 15.0 & 31.5 & 34.0 & 12.5 & 4.27 \\
Limited financial information (i.e. ROI) & 1.0 & 4.5 & 17.5 & 30.5 & 34.0 & 12.5 & 4.28 \\
Limited involvement of private sectors & 1.0 & 5.5 & 15.0 & 29.5 & 35.0 & 14.0 & 4.33 \\
Lack of awareness & 2.0 & 8.0 & 10.5 & 25.0 & 29.5 & 25.0 & 4.45 \\
Unfavorable costs, subsidies and energy prices & 1.0 & 7.5 & 12.0 & 22.0 & 37.0 & 20.5 & 4.47 \\
Lack of access to the technology & 3.0 & 7.0 & 19.0 & 25.0 & 30.0 & 16.0 & 4.20 \\
Lack of social acceptance & 3.0 & 5.5 & 14.0 & 29.0 & 29.5 & 19.0 & 4.34 \\
Lack of cost-benefit valuation & 2.5 & 6.0 & 11.0 & 30.0 & 32.5 & 18.0 & 4.39 \\
Unfavorable energy sectors policies & 2.0 & 7.0 & 13.0 & 28.5 & 33.0 & 16.5 & 4.34 \\
\hline
\end{tabular}

Note: rounded to $100 \%$, Mean is calculated in a total point of $6 . \mathrm{SD}=$ Strongly Disagree, $\mathrm{D}=$ Disagree,

$\mathrm{MD}=$ Moderately Disagree, $\mathrm{MA}=$ Moderately Agree, $\mathrm{A}=$ Agree, $\mathrm{SA}=$ Strongly Agree

TABLE 11. ANOVA TEST ON BARRIERS

\begin{tabular}{|c|c|c|c|c|c|c|}
\hline \multirow[b]{2}{*}{ Items } & \multicolumn{3}{|l|}{ Ethnicity } & \multicolumn{3}{|c|}{ Electricity Consumption } \\
\hline & P-value & $\begin{array}{l}\text { Highest } \\
\text { Mean }\end{array}$ & $\begin{array}{l}\text { Mean } \\
\text { Group }\end{array}$ & P-value & $\begin{array}{l}\text { Highest } \\
\text { Mean }\end{array}$ & Mean Group \\
\hline $\begin{array}{l}\text { Limited information on } \\
\text { Renewable energy }\end{array}$ & $0.054 * *$ & 4.56 & Chinese & .475 & 4.37 & $5000-1000 \mathrm{kWh}$ \\
\hline Inadequate financing & $0.055^{*}$ & 4.81 & Chinese & .828 & 4.62 & $5000-1000 \mathrm{kWh}$ \\
\hline $\begin{array}{l}\text { Limited financial } \\
\text { information (i.e. ROI) }\end{array}$ & .115 & 4.70 & Chinese & .520 & 4.87 & $5000-1000 \mathrm{kWh}$ \\
\hline $\begin{array}{l}\text { Limited involvement of } \\
\text { private sectors }\end{array}$ & .386 & 4.62 & Chinese & .746 & 4.62 & $3000-5000 \mathrm{kWh}$ \\
\hline Lack of awareness & .451 & 4.77 & Chinese & .920 & 4.60 & $5000-10000 \mathrm{kWh}$ \\
\hline $\begin{array}{l}\text { Unfavorable costs, subsidies } \\
\text { and energy prices }\end{array}$ & .181 & 4.92 & Chinese & .213 & 4.87 & $5000-1000 \mathrm{kWh}$ \\
\hline $\begin{array}{l}\text { Lack of access to the } \\
\text { technology }\end{array}$ & .197 & 4.62 & Chinese & $0.050 * *$ & 4.50 & $500-1000 \mathrm{kWh}$ \\
\hline Lack of social acceptance & .212 & 4.70 & Chinese & .552 & 4.50 & $3000-500 \mathrm{kWh}$ \\
\hline $\begin{array}{l}\text { Lack of valuation of cost and } \\
\text { benefits }\end{array}$ & .216 & 4.81 & Chinese & .234 & 4.75 & $5000-1000 \mathrm{kWh}$ \\
\hline $\begin{array}{l}\text { Unfavorable energy sectors } \\
\text { policies }\end{array}$ & .355 & 4.66 & Chinese & .732 & 4.62 & $5000-1000 \mathrm{kWh}$ \\
\hline
\end{tabular}

\subsection{Future Outlook and Policy Participation for Renewable Energy Development}

The level of interest, awareness, lack of availability and limited access to information are the major barriers to effective renewable energy development in Malaysia. The respondents offered a number of solutions to enhance the socialisation process. Around $70 \%$ of the respondents argue that introduction of a new renewable energy project will tremendously boosts up the level of local residences' awareness (Table 12). Hence, community based renewable energy development [35] is the choice among the respondents in Malaysia. However, there exist questions on the organisational and regulatory participation to successful renewable energy initiative. Table 13 
reports that respondents place highest importance on government on where policy issues are concerned, while research institutes should be responsible on innovation of customer friendly renewable energy technology. Although the lowest importance was given to municipalities, the government has to bring in various changes to existing regulatory frameworks, community education programs and developing retail chains to enhance mass access to renewable energy technologies. The ANOVA tests (not reported here) on institutional priority based on ethnicity, size of establishment and average monthly use of electricity do not reveal any significant differences among the institutions.

\section{TABLE 12. NeW PROJECT INCREASES LEVEL OF AWARENESS}

\begin{tabular}{lll}
\hline Respondents' Opinion & Frequency & Percent \\
\hline No Opinion & 13 & 6.5 \\
Disagree & 6 & 3.0 \\
Agree & 112 & 56.0 \\
Strongly Agree & 48 & 24.0 \\
Total & 179 & 89.5 \\
Missing & 21 & 10.5 \\
\hline & 200 & 100.0 \\
\hline
\end{tabular}

TABle 13. Institutional Priority to DeVelop Renewable EnERgy SECTOR (\% OF RESPONDENTS)

\begin{tabular}{llll}
\hline Institutions & No Priority & Average & Top Priority \\
\hline Government & 5.0 & 22.0 & 73.0 \\
Universities and Research Institutions & 3.0 & 27.0 & 70.0 \\
Private sector & 5.0 & 38.0 & 57.0 \\
Electric utilities department & 3.0 & 42.0 & 55.0 \\
Municipalities & 4.0 & 58.0 & 38.0 \\
\hline
\end{tabular}

Regulators have plenty of challenges in order to develop social acceptance of renewable energy in Malaysia. What are some of the areas that the government should take actions on for sustainable renewable energy development? Table 14 shows respondents' opinion regarding government's initiative. Roughly $70 \%$ of the respondents think that the government should not be directly involved with renewable energy business, rather it should only assist in policies to clear up policy barriers. Similarly, the respondents do not want the government to demonstrate projects. These are clear evidences of the respondents' willingness to see more private sector investment and engagement into renewable energy development. More than $50 \%$ of the respondents want the government to make information on renewable energy accessible by mass users. Nearly $40 \%$ of the respondents require the government to penetrate academic curriculum to develop clear understanding among the youth. On top of all, the respondents want government's intervention. However, that intervention should not go beyond policy level. The government should make information available to mass users and let the private sector invest and manage renewable energy sector. 
Table 14: Government Initiative to Develop Sustainable Renewable Energy Sector

\begin{tabular}{|c|c|c|c|}
\hline \multirow{2}{*}{ Government should } & \multicolumn{2}{|c|}{ Responses } & \multirow{2}{*}{$\begin{array}{l}\text { Percent } \\
\text { of Cases }\end{array}$} \\
\hline & $\mathbf{N}$ & Percent & \\
\hline Directly promote renewable energies & 84 & $26.20 \%$ & $47.50 \%$ \\
\hline Support pilot demonstration project for different technologies & 53 & $16.50 \%$ & $29.90 \%$ \\
\hline Place renewable energy into academic curriculum & 71 & $22.10 \%$ & $40.10 \%$ \\
\hline Make information accessible by mass users & 96 & $29.90 \%$ & $54.20 \%$ \\
\hline Not be involved with renewable energy & 17 & $5.30 \%$ & $9.60 \%$ \\
\hline Total & 321 & $100.00 \%$ & $181.40 \%$ \\
\hline
\end{tabular}

Note: Includes multiple responses

\section{CONCLUSION}

Government, private sector and users need to face multi-dimensional social barriers to sustainable renewable energy development. At present, Malaysians mostly depend on conventional energy sources for electricity and other energy demands, which explains why the use of renewable sources is insignificant. The respondents identified four major issues. Firstly, there has to be sufficient regulatory and policy assistance starting from policies to motivate investment in renewable energy technology innovation, making information available to be accessed by mass users and creating conducive environment for private sector to capitalise in this sector. Similar to various studies conducted in the western contexts [5], [35], [36] a community based renewable sector development would be a good start. There exists lack of awareness among Malaysians regarding the benefits and challenges of renewable energies. As argued in Fredric [37], government and private sector investors can develop marketing programs to create awareness in communities to increase the use of renewable energies.

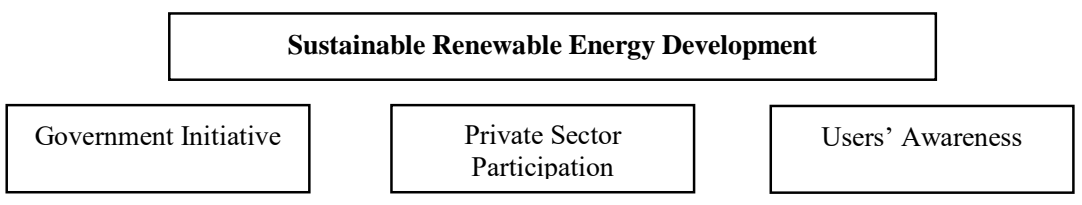

Fig. 1. Dimensions of Successful Renewable Energy Development in Malaysia.

The role of banks and financial institutions in arranging financing for renewable energy investment is crucial. Investment in renewable energy at the mass user level is quite expensive. Hence, West et al. [38] argued that government should offer economic incentives to investors and users of renewable energy technologies. Similarly, respondents in this study have also argued that lack of financial information and limited financing availability are major issues while deciding to transform conventional to renewable energy. However, similar to the western contexts [5], [6]. Malaysians are not ready to pay extra to save the environment. They do not like to see their tax burden increase because people are not using environmentally safe technologies. Therefore, the government has more challenges than those of the private sector and users of renewable energy. The respondents also supported small-scale renewable energy projects to be established locally to create awareness among the people. Most of the respondents in this study have been using solar energy for various purposes. Solar energy technologies are relatively easy to use. The government of Malaysia should place added importance to solar energy to initiate sustainable renewable energy development. Finally, the study reveals three dimensions of successful renewable energy development for Malaysia, as shown in Fig. 1. 


\section{REFERENCES}

[1] Wüstenhagen R., Wolsink M., Bürer M. J. Social Acceptance of Renewable Energy Innovation: an Introduction to the Concept. Energy Policy 2007:35:2683-2691. doi:10.1016/j.enpol.2006.12.001

[2] Alam S. S., Hashim N. H. N., Rashid M., Omar N. A., Ahsan N., Ismail M. D. Small-scale households renewable energy usage intention: Theoretical development and empirical settings. Renewable Energy 2014:68:255-263. doi:10.1016/j.renene.2014.02.010

[3] Mallett A. Social acceptance of renewable energy innovations: The role of technology cooperation in urban Mexico. Energy Policy 2007:35(5):2790-2798. doi:10.1016/j.enpol.2006.12.008

[4] Richards G., Noble B., Belcher K. Barriers to renewable energy development: A case study of large-scale wind energy in Saskatchewan, Canada. Energy Policy 2012:42:691-698. doi:10.1016/j.enpol.2011.12.049

[5] Stephenson J., Loannou M. Social Acceptance of Renewable Electricity Developments in New Zealand. Centre for the Study of Agriculture, Food and Environment. University of Otago: Energy Efficiency and Conservation Authority, 2010.

[6] Zografakis N., Sifaki E., Pagalou M., Nikitaki G., Psarakis V., Tsagarakis K. P. Assessment of public acceptance and willingness to pay for renewable energy sources in Crete. Renewable and Sustainable Energy Reviews 2010:14(3):1088-1095. doi:10.1016/j.rser.2009.11.009

[7] Ahmad Fauzi H. Energy Efficiency and Renewable Energy in Malaysia. Energy Commission, 2009 [Online]. Available: www.teeam.com/st paper_15july09.pdf

[8] Jacobsson S., Johnson A. The diffusion of renewable energy technology: an analytical framework and key issues for research. Energy Policy 2000:28(9):625-640. doi:10.1016/S0301-4215(00)00041-0

[9] Rogers E. M. Diffusion of Innovations. New York: Free Press of Glencoe, 1962.

[10] Straub E. T. Understanding Technology Adoption: Theory and Future Directions for Informal Learning. Review of Educational Research 2009:79(2):625-649. doi:10.3102/0034654308325896

[11] Dalton G. J., Lockington D. A., Baldock T. E. A survey of tourist attitudes to renewable energy supply in Australian hotel accommodation. Renewable Energy 2008:33(10):2174-2185. doi:10.1016/j.renene.2007.12.016

[12] Faiers A., Neame C. Consumer attitudes towards domestic solar power systems. Energy Policy 2006:34(14):17971806. doi:10.1016/j.enpol.2005.01.001

[13] Sovacool B. K., Bulan L. C. Energy security and hydropower development in Malaysia: The drivers and challenges facing the Sarawak Corridor of Renewable Energy (SCORE). Renewable Energy 2012:40(1):113-129. doi:10.1016/i.renene.2011.09.032

[14] Ong H. C., Mahlia T. M. I., Masjuki H. H. A review on energy pattern and policy for transportation sector in Malaysia. Renewable and Sustainable Energy Reviews 2012:16(1):532-542. doi:10.1016/j.rser.2011.08.019

[15] Mekhilef S., Safari A., Mustaffa W. E. S., Saidur R., Omar R., Younis M. A. A. Solar energy in Malaysia: Current state and prospects. Renewable and Sustainable Energy Reviews 2012:16(1):386-396. doi:10.1016/j.rser.2011.08.003

[16] Chua S. C., Oh T. H. Solar energy outlook in Malaysia. Renewable and Sustainable Energy Reviews 2012:16(1):564574. doi:10.1016/j.rser.2011.08.022

[17] Tye Y. Y., Lee K. T., Wan Abdullah W. N., Leh C. P. Second-generation bioethanol as a sustainable energy source in Malaysia transportation sector: Status, potential and future prospects. Renewable and Sustainable Energy Reviews 2011:15(9):4521-4536. doi:10.1016/j.rser.2011.07.099

[18] Sovacool B. K., Drupady I. M. Examining the Small Renewable Energy Power (SREP) Program in Malaysia. Energy Policy 2011:39(11):7244-7256. doi:10.1016/i.enpol.2011.08.045

[19] Mohammed M. A. A., Salmiaton A., Wan Azlina W. A. K. G., Mohammad Amran M. S., Fakhru'l-Razi A., TaufiqYap Y. H. Hydrogen rich gas from oil palm biomass as a potential source of renewable energy in Malaysia. Renewable and Sustainable Energy Reviews 2011:15(2):1258-1270. doi:10.1016/j.rser.2010.10.003

[20] Poh K. M., Kong H. W. Renewable energy in Malaysia: a policy analysis. Energy for Sustainable Development 2002:6(3):31-39. doi:10.1016/S0973-0826(08)60323-3

[21] Hoi Why K. Biomass energy utilisation in Malaysia - Prospects and problems. Renewable Energy 1999:16(14):1122-1127.

[22] Mohd Noh D. Renewable energy update: Malaysia. Renewable Energy 1995:6(4):435-439. doi:10.1016/09601481(94)00070-M

[23] Mekhilef S., Saidur R., Safari A., Mustaffa W. E. S. B. Biomass energy in Malaysia: Current state and prospects. Renewable and Sustainable Energy Reviews 2011:15(7):3360-3370. doi:10.1016/j.rser.2011.04.016

[24] Ahmad S., Kadir M. Z. A. A., Shafie S. Current perspective of the renewable energy development in Malaysia. Renewable and Sustainable Energy Reviews 2011:15(2):897-904. doi:10.1016/j.rser.2010.11.009

[25] Hashim H., Ho W. S. Renewable energy policies and initiatives for a sustainable energy future in Malaysia. Renewable and Sustainable Energy Reviews 2011:15(9):4780-4787. doi:10.1016/j.rser.2011.07.073

[26] Jayaraman K., Haron H., Sung G. B., Lin S. K. Consumer reflections on the usage of plastic bags to parcel hot edible items: an empirical study in Malaysia. Journal of Cleaner Production 2011:19(13):1527-1535. doi:10.1016/i.jclepro.2011.03.019 
[27] Oh T. H., Pang S. Y., Chua S. C. Energy policy and alternative energy in Malaysia: Issues and challenges for sustainable growth. Renewable and Sustainable Energy Reviews 2010:14(4):1241-1252. doi:10.1016/j.rser.2009.12.003

[28] Chua S. C., Oh T. H. Green progress and prospect in Malaysia. Renewable and Sustainable Energy Reviews 2011:15(6):2850-2861. doi:10.1016/j.rser.2011.03.008

[29] Manan Z. A., Shiun L. J., Alwi S. R. W., Hashim H., Kannan K. S., Mokhtar N., Ismail A. Z. Energy Efficiency Award system in Malaysia for energy sustainability. Renewable and Sustainable Energy Reviews 2010:14(8):22792289. doi:10.1016/j.rser.2010.04.013

[30] Gan P. Y., Li Z. An econometric study on long-term energy outlook and the implications of renewable energy utilization in Malaysia. Energy Policy 2008:36(2):890-899. doi:10.1016/j.enpol.2007.11.003

[31] Malhotra N. K. Marketing Research: An Applied Orientation, 5th ed. India: Pearson Education, 2008.

[32] Gorsuch R. L. Factor Analysis, 2nd ed. Hillsdale, NJ: Erlbaum, 1983.

[33] Kline P. An Easy Guide to Factor Analysis. New York: Routledge, 1994.

[34] Hair J. F. J., Anderson R. E., Tatham R. L., Black W. C. Multivariate Data Analysis, 5th ed. Upper Saddle River, New Jersey: Prentice Hall, 1998.

[35] Rogers J. C., Simmons E. A., Convery I., Weatherall A. Social impacts of community renewable energy projects: findings from a woodfuel case study. Energy Policy 2011:42:239-247. doi:10.1016/j.enpol.2011.11.081

[36] Rogers J. C., Simmons E. A., Convery I., Weatherall A. Public perceptions of opportunities for community-based renewable energy projects. Energy Policy 2008:36(11):4217-4226. doi:10.1016/j.enpol.2008.07.028

[37] Fredric C. M. Green electricity policies in the United States: case study. Energy Policy 2005:33(18):2398-2410. doi:10.1016/j.enpol.2004.05.011

[38] West J., Bailey I., Winter M. Renewable energy policy and public perceptions of renewable energy: A cultural theory approach. Energy Policy 2010:38:5739-5748. doi:10.1016/j.enpol.2010.05.024

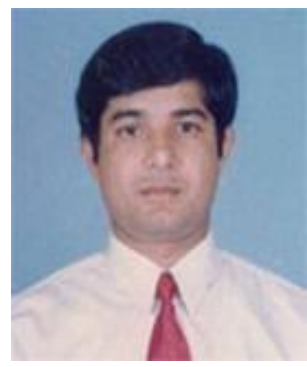

Dr. Syed Shah Alam is an Associate Professor at the Faculty of Economics and Management, Universiti Kebangsaan Malaysia (The National University of Malaysia). Prior to joining to the National University of Malaysia, he taught at Universiti Teknologi MARA (UiTM), Malaysia and Multimedia University Malaysia (MMU). Dr Alam is the recipient of an "Excellent Service Award" at the Universiti Kebangsaan Malaysia in 2011.

He has authored for four books and more than 100 academic articles in business and Ecommerce area. Over the past 5 years he has been actively involved in social enterprises development program in Malaysia with a special interest in participatory action research and social enterprises projects. He focuses on developing and promoting linkages and collaborative social enterprises activities between Malaysian educational and other institutions. He has served as the secretary for "First International Research Conference on Social Business' 2013” held in Universiti Kebangsaan Malaysia.

Email: shahalam@ukm.edu.my

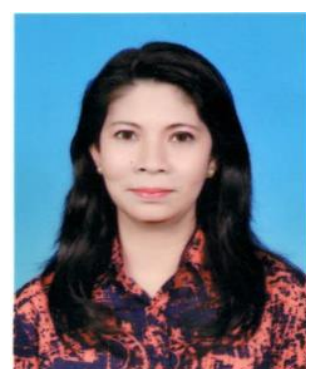

Nor Fariza Mohd Nor (Ph.D) received the Ph.D degree from the University of Malaya, Malaysia, in Applied Linguistics, in 2008. She received her Master degree in master in English for specific purpose from the University of Warwick, U.K. in 1998 and her Bachelor (Hons) degree from the University of Lancaster, U.K. in 1990.

Nor Fariza is an Associate Professor at the School of Language Studies and Linguistics (SoLLS), Faculty of Social Sciences and Humanities, National University of Malaysia (UKM). She began her career as an English language teacher at SoLLS, before she pursued her master degree in 1997. She completed her master degree in 1998 and returned to UKM. She then began her career as a lecturer and became a senior lecturer in 1999. Nor Fariza later pursued her education in Ph.D and convocated in 2008.

She teaches discourse and pragmatics, to both the undergraduate and postgraduate students. She also supervises students at degree level, master and Ph.D level on topics such as language learning, discourse analysis and sociolinguistics. In addition, Nor Fariza has been invited as external examiner to evaluate thesis of both master and Ph.D students, in UKM and other public and private universities in Malaysia. She is currently the editor-in-chief for GEMA Online ${ }^{\circledR}$ Journal of Language Studies, a journal which focuses on linguistics, English language, Malay language and foreign language teaching and learning, literature and translation studies. GEMA Online Journal is indexed in established databases such as Elsevier (Scopus), DOAJ, Wiley-Blackwell, Ebsco, Linguist list, Asean Citation Index, Islamic World Citation Center and most recently in ESCI (indexed by Thomson Reuters). She has been the editor-in-chief for the past 4 years. Due to her vast experience in managing journal, she has been invited to present talks on journal management by several higher learning institutions.

E-mail: fariza@ukm.edu.my 


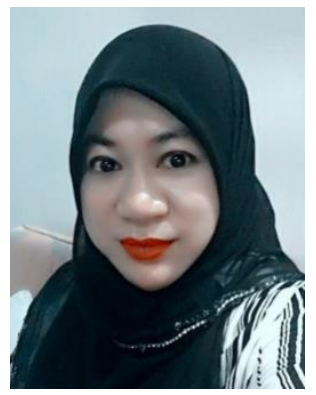

Associate Professor Dr. Maisarah Ahmad presently is the Chief Executive Officer for Women Innovation Academy (MyWIN). Prior assuming her current post, she was the first to lead the newly incepted Income Generation and Business Development Department under the Pro Vice Chancellor's Office Universiti Kebangsaan Malaysia (UKM), who took up her post on the $15^{\text {th }}$ of October 2015. Prior to her appointment as Executive Deputy Director, she was the Deputy Dean for Research, Innovation and Industry Engagement, Faculty of Economics and Management.

Dr. Maisarah also heads the Consumer and Consumerism Research $\boldsymbol{C o R E}$-UKM and serves as a Deputy Treasurer for Malaysian Consumer and Family Economics Association (MACFEA) and a member of Consumer Forum Malaysia within the purview of Malaysian Communications and Multimedia Commission, Ministry of Communication and Multimedia. Maisarah is also an Honorary Professor of Marketing, an appointment by the Government of Cambodia for IIC University of Technology Cambodia. Her research passion is predominantly in areas of consumer insights in particular where marketing concepts and theories are fused into nonbusiness context such as recycling, food security and religion, to name a few. Uncovering and exploring consumer socialization is another passion of hers. She has published numerous articles and books on related matters.

Email: sara@ukm.edu.my

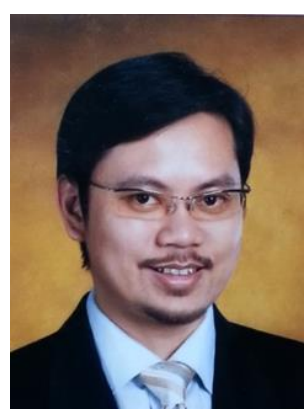

Nik M. Hazrul Nik Hashim is an Associate Professor of Marketing at UKM-Graduate School of Business, National University of Malaysia. He holds a Ph.D in Marketing from the University of Melbourne in 2009. He has more than fifteen years of experience as an academician, including a casual teaching stint in Australia. He is currently the Head of Doctoral Programs at the faculty. He has published in reputable international journals such as Renewable Energy, Journal of Sustainability Science and Management, and Australian Journal of Basic and Applied Sciences. Nik is also the co-author of Product Management \& Strategy, a book published by McGraw-Hill. He specializes in Product Innovation and New Product Development from the marketing perspective. His research interests centre on product strategy and performance, packaging and prototypes, product rollouts, green products, and environmental marketing.

He has been a consultant specializing in development and environmental marketing strategies for new products for several innovation companies: Center for Collaborative Innovation, Biobiz Innovation Research Group, and Malaysian Foundation for Innovation. His teaching performance has consistently been ranked among the highest at the faculty and university level, hence is the recipient of numerous teaching and research awards. 